\title{
Research on the Development Strategies of Rural Tourism under the Background of New Urbanization
}

\author{
Xiya Wang \\ Xi'an Peihua University, Xi'an, 710125, China
}

Keywords: Rural tourism, New urbanization, Rural urbanization

\begin{abstract}
The new urbanization construction provides a new opportunity for the development of rural tourism in our country, which brings about the direction change of rural tourism development. This paper expounds the problems of rural tourism development under the background of the new urbanization in China and suggests that we should strengthen ecological protection consciousness, attach importance to the conservation of the rural culture and cultivate the rural tourism talents to promote the development of rural tourism better and faster.
\end{abstract}

\section{Introduction}

Rural tourism is a kind of travel which takes place in the rural area based on the natural and human resources of the countryside. As the rural areas have unique resources different from urban areas, both ecological or human, has more traditional characteristics, especially in agriculture, rural ecological culture of organic food and other key resources, more to promote the development of rural tourism has become a pillar. Rural tourism products provide all the products and services directly related to rural areas, such as rural culture, rural industry, rural environment and so on. The original ecological characteristics of these basic factors are rural village, the original ecological environment, rural culture and rural village resources to tourism products form, provide in-depth experience of opportunities for city residents. The goal of urbanization construction is different from the traditional model of urbanization, pay more attention to maintain the quality of urbanization and sustainable development, so the construction of new urbanization in the humanities and the construction of the related content as the focus of the work object, compared with the traditional urban construction has the characteristics of very prominent, the fundamental connotation of these features also reflects the new urbanization is different from the traditional urbanization. The new urbanization has ecological characteristics, because of the importance of sustainable development, therefore, in the construction of new urbanization, the ecological construction should be ensured. The new urbanization has the characteristics of highlighting the characteristics of the city, the construction of new urbanization will focus on the development of the town's own characteristics. Therefore, the urbanization construction planning is closely related to the characteristics of the urban areas. Therefore, it is of great practical significance to promote the development of rural tourism from the perspective of new urbanization.

\section{Existing Problems of Rural Tourism under the Background of New Urbanization}

Declination of Ecological Quality. Rural tourism belongs to the category of ecological agriculture and ecological tourism. The lack of planning and protection awareness, coupled with the influx of tourists' disorderly development, resulting in greater pressure to the original fragile ecological environment, water, air and noise pollution brought tourism of traditional pattern, affect the sustainable development of resources. Due to the extensive use of pesticides, chemical fertilizers, plastic sheeting and dispose of garbage, straw burning, rural water, soil and air pollution is serious, directly affect the food basket, rice bag and water tank safety. Relieve and even eliminate the current China rural ecological security threat, not only to water, latrines, garbage treatment, livestock and poultry to captive; adjust the mode of development, industrial structure, vigorously develop the green economy, circular economy, service economy, ecological value replacement. To improve the stability of rural ecosystem, on the one hand, we should strengthen the management of urban and rural 
planning and construction, on the other hand, we should control the degree of disturbance to the ecosystem, so that it does not exceed the ability of the ecological system. Rural ecological landscape is one of the main attractions of rural tourism development. Tourism visualization and scenario of ecological landscape is an important direction of rural ecological construction. The lack of ecological environment development mode of the protection of the ecological environment, resulting in the gradual disappearance of the original ecological landscape of the countryside, replaced by a modern building. The countryside is not only the raw material of the city, but also the important consumption place of the city economy. Under the background of the new urbanization, the development of rural tourism, ignoring the rural ecological construction, will eventually decline.

Damage of Rural Culture. Farmers, agriculture and rural areas are the basic elements of rural tourism. In the rapid urbanization tide, local landscape environment and regional culture are faced with hitherto unknown impact, the core value of rural tourism under the impact of market, the quality of culture is changing rapidly, causing unsustainable resources. In some places, excessive pursuit of commercial interests, engage in cultural landscape construction be busy at putting up installations, resulting in rural culture fade, losing uniqueness. The modern culture of the city has a great impact on the rural production and life style, so that it gradually loses its local flavor, and the authenticity of the culture goes further and further. Rural culture is the source and important part of Chinese culture, and also the foundation and support of rural tourism development. The occurrence of people creates in the course of social development in rural areas of all kinds of material and spiritual wealth, whether it is farming culture, folk architecture and life custom, or national beliefs, folk art and folk art, are carrying the China precious cultural heritage, contains a profound historical and cultural information, embodies the people's life the value of care. Chinese most material and non-material cultural heritage are distributed in the village, village is the carrier of Chinese traditional culture, rural culture is the source of Chinese culture and is an important gene pool, rural residents and stored in nostalgia left behind people nostalgic spiritual home, is the foundation and support for rural tourism development. We should correctly understand and give full play to the cultural value of rural tourism, and effectively protect and inherit the rural culture. This is to ensure that rural tourism has an independent cultural value and the necessary conditions for tourism charm, but also an important guarantee for China to take a new road to urbanization.

Lack of Professional Talents. Although the development of rural tourism is faster, and the scale of development is gradually expanding, but due to the lack of rural tourism professionals, the new rural tourism development under the background of urbanization. Many rural tourism workers are farmers, have not received formal education and training, but also the lack of tourism development and management experience, lack of awareness of tourism. Although the outskirts of the city have begun to enjoy the success of tourism development, but the country has not yet achieved tourism development. Due to the rural education level is low, leading to the rural villagers for lack of understanding of the concept of tourism, just think the rural empty house can be used for the reception of tourists, tourist attractions and planning for construction of scenic spots and tourism, tourism product development and other issues have no idea. Therefore, the problems of rural tourism, such as the low level of management, the lack of income level and the backwardness of the development level. Since China's rural development, the country began to gradually increase the training of professional personnel in rural tourism, but the slow pace of development, the main source of most engaged in rural tourism personnel in rural labor itself, a serious lack of professional tourism personnel. And, as a result of the development of rural tourism, a lot of people began to invest in rural tourism, a lot of nonprofessional people because of the lack of professional knowledge, the development of rural tourism has a serious negative effect. At the same time, according to the country tourism personnel training seriously insufficient, the state and local governments did not focus on, but there is no related development investment, leading to the development situation of rural tourism has been in lack of the professional. For the development of rural tourism, a lot of tourism professionals prefer to be diverted to develop, but also do not want to engage in rural tourism. It leads to the loss of tourism professionals, and has a serious impact on the development of rural tourism. 


\section{Countermeasures of Rural Tourism under the Background of New Urbanization}

Strengthen Ecological Conservation Awareness. Good ecological environment is an important rural tourism resources. Efforts should be made to promote green tourism and low-carbon tourism in rural areas to enrich the content of eco-tourism, and to develop new tourism space and areas. The development of rural tourism on the premise of ecological protection, mining village ecological connotation, improve the ecological quality of rural tourism, rural ecological village, create a unique artistic culture, realize the ecological goals of new urbanization. Rural tourism will effectively realize the transformation and upgrading of rural production and life style, protect the ecological environment, improve the living environment in rural areas, and achieve a win-win situation of production, ecology and life. China has a vast territory, the natural environment and cultural background of regional differences, different types, different stages of development of rural areas should be adapted to local conditions. Tourism is optional but not mandatory mode of development, choose their own path of development is the essence of the beautiful countryside and the construction of ecological civilization. The development of rural tourism should adapt to the demands of ecological system. We cannot ignore the native nature, sensitivity and adaptability of the species, which can lead to the ecological risk of alien species invasion. Environmental capacity should be taken into account in formulating development plan. The ecological awareness into the planning, development and operation management of the whole process. Through ecological restoration, the ecological communities in rural areas can be self-sufficient, so that the damaged rural environment can be improved and improved. At the same time, we should strengthen the training and guidance of rural tourism knowledge, strengthen the awareness of rural ecological environment protection.

Value Rural Culture Protection. Rural culture is the source and important part of Chinese culture, and also the soul of rural tourism. However, under the impact of urbanization and modernization, the traditional rural culture is facing the plight of destruction or even disappear. Must take the rural tourism as an important carrier, strengthen the rural tourism cultural region types and cultural value, cultural influence of urbanization on rural tourism, rural tourism, rural tourism and cultural integration and cultural protection and reconstruction and development of theoretical research and practical application, to better promote the rural cultural heritage and the local characteristics of shaping and development of tourism industry. It is an important task to develop rural tourism and rural culture. Different regions have unique natural endowment, cultural endowment. Agricultural environment, agricultural landscape and cultural connotation are the core attraction of rural tourism. It is necessary to construct the rural areas which embody the diversity of the local culture, the historical memory, the cultural context, the regional features and the national characteristics, and form the rural tourism development model which is in line with the reality and characteristics. The development of rural tourism should not weaken the traditional local culture, but should be protected, utilized and promoted in the development. The village in the drive of tourism development, area, especially the superior location, nature and culture protection better city and suburban areas, will gradually become the new urbanization regional advantages of both city and countryside, urbanization development in these areas is an important part of Chinese new urbanization development, which will provide important reference for the new the development of urbanization.

Nurture Rural Tourism Professionals. The government should attach great importance to the professional training of rural tourism talents, and put the planning issues in tourism planning. Government departments should focus on the concept of rural villagers and farmers' knowledge and skills of tourism in two areas. The government departments through the active capital investment, gradually to the rural tourism for the concept of tourism development, and the farmers of rural tourism professional knowledge and skills training and training. With the continuous development of rural tourism, the serious shortage of qualified personnel with high quality and high skill level. Therefore, in order to get a better development, rural tourism must be trained in the professional management of rural tourism. We can improve the professional ability of rural tourism practitioners through the training of the original rural tourists to the college, and train more talents for rural tourism. 
Improve the quality of rural tourism practitioners is the basis for development. Education and training. On the one hand, increasing investment in tourism education. Through the cultivation of college students, the establishment of a high-quality team of rural tourism, in order to continuously improve marketing and publicity. On the other hand, to increase the training of some of the tourism practitioners. To enhance the effectiveness of training, training for different positions classified, rich training content, tourism laws, regulations, service standards, reception etiquette. We should pay attention to the training and selection of the backbone of the business and skills, promote and promote the self-learning and self-education of the staff, and improve the quality of rural tourism practitioners as a whole. Strengthen the training of the laws and regulations of the employees, the cultivation of corporate culture, the etiquette training, the operation skills and the service concept transformation.

\section{Conclusion}

Rural tourism is an important means of economic development, and the promotion of new urbanization is the trend in our country. We should pay attention to the good opportunity provided by the new urbanization construction for rural tourism development. At the same time, we cannot ignore the negative impact of urban civilization on rural tourism. Under the background of the construction of new urbanization, we should make great efforts to strengthen the construction of ecological civilization, rural culture and professional talents to realize the development and prosperity of rural tourism.

\section{References}

[1] Li Yingli, Wang Can, Study on the Ecological Transformation of Rural Tourism Economy under New Urbanization [J]. Issues in Agricultural Economy, 2015(6): 29-34.

[2] Sun Yuan, Xia Xueying, Liaoning Rural Tourism Development Research from the Perspective of New Urbanization [J]. Journal of Central South University of Forestry \& Technology (Social Sciences), 2015, 9(3): 69-72.

[3] Bingbing Liu, Chenghao Ren, How to Develop Chinese Rural Tourism in the Context of New Urbanization? [J]. Asian Agricultural Research 2016, 8(5) :27-28+32.

[4] Wang Xinting, Zhao Jie, Fang Shimin, Problems and Countermeasures of the Development of Beautiful RuralTourismunder the Background of New Urbanization- A Case Study of Meilinqiao in XiangtanCity [J]. Hunan Agricultural Sciences, 2016(6): 90-93. 